\title{
Zeta potential and electrophoretic mobility for the recovery of a saline soil with organic amendments
}

\section{Potencial zeta e mobilidade eletroforética para a recuperação de um solo salino com alterações orgânicas}

\author{
Judith Prieto Méndez¹, Francisco Prieto García1, Nallely Trejo González¹, \\ Yolanda Marmolejo Santillán'1, Otilio Arturo Acevedo Sandoval'
}

'Universidad Autonoma del Estado de Hidalgo/UAEH, Pachuca, Hidalgo, Mexico

*Corresponding author: prietog@uaeh.edu.mx

Received in March 16, 2018 and approved in June 9, 2018

\begin{abstract}
The accumulation of salts in the soil profile produces conditions that affect the growth of crops. The effects of these conditions on crops and the intensity of these effects depend on the quantity and type of salts that predominate and are also influenced by soil characteristics and climate, among other aspects. The salinization of agricultural soils is a serious problem facing agriculture today. The use of organic amendments has increased in recent years, acting on the texture of the soil, correcting compaction or granularity problems, and influencing chemical and/or biological reactions. The objectives of this work were to analyze the use of compost and vermicompost using different analysis techniques to determine the influence of conditions on the remediation of a saline soil. In saturation extracts of soil, compost, and vermicompost, a Zeta potential value 2.34-2.44 times more negative (more-stable colloids) than that in the soil colloids was observed in the amendments. The values of electrophoretic mobility were more negative in the organic amendments compared with the soil. This is the first time that these parameters have been reported for these purposes and for a saline soil. In this study, the soil has low organic matter content (1.65\%), so these amendments are expected to improve soil quality and texture, achieving the recovery of saline soils.
\end{abstract}

Index terms: Salinization; Remediation; Vermicompost.

\begin{abstract}
RESUMO
A acumulação de sais no perfil do solo produz condições que afetam o crescimento das culturas, seus efeitos e intensidade dependem da quantidade e tipo de sais que predominam, influenciando também as características do solo e do clima, entre outros aspectos. A salinização de solos agrícolas é um grave problema para a agricultura hoje. As emendas orgânicas têm aumentado nos últimos anos, atuam sobre a textura do solo, corrigindo problemas de compactação ou granularidade e atuando sobre as reações químicas e/ou biológicas. Os objetivos foram, de um lado, elaborar compost e vermicompost, também para avaliar suas propriedades físico-químicas e factibilidade na remediação do solo salino de uma região agrícola mexicana. Para isso, utilizamos potencial Z, movimentação eletroforética, ponto isoelétrico, condutividade elétrica, $\mathrm{pH}$, tamanho de partículas coloidais e acoplamento espectroscópico (MEB-EDS). Como os resultados, os extratos de saturação do solo, composto e vermicompost tiveram valor entre 2,34 e 2,44, mais negativos no potencial Zeta (colóides mais estáveis) para as emendas do que nos colóides do solo. A mobilidade eletroforética apresentou valores mais negativos nas emendas orgânicas em relação ao solo. Esta é a primeira vez que esses parâmetros são relatados para esses propósitos, e para um solo salino, o solo em estudo possui baixos teores de matéria orgânica (1,65\%), e espera-se que essas alterações melhorem sua qualidade e textura indo a recuperação de solos salinos.
\end{abstract}

Termos para indexação: Salinização; Remediação; vermicomposto.

\section{INTRODUCTION}

Soil is becoming increasingly degraded as the human population grows. Soil is an important natural resource that needs to be conserved, so that it maintains its ability to be productive, and for this purpose, sustainable practices must be proposed and applied to recover those lands degraded by poor human management, including land that has undergone soil salinization (Murli et al., 2016).
The salinity of the soil, in several of its manifestations, has been the cause, to a greater or lesser degree, of the reduction in the productive capacity of soils in many regions of the world (Comesw; González; Conti, 2009; Vijayasatya et al., 2015). Salinity (occurring as primary salinization) is common in arid and semiarid regions where evapotranspiration exceeds precipitation; in these types of regions, irrigation (which leads to secondary salinization) is used to satisfy the water requirements of the 
crops (Ouni et al., 2013; Lin et al., 2016). The accumulation of salts in the soil profile produces conditions that affect the growth of most crops; the effects and the intensity of these conditions can be diverse depending on the amount and type of salts that dominate, with crops also being influenced by soil characteristics and climate, among other things (Busoms et al., 2015).

Soil amendment has increased in recent years due to soil problems, acting mainly on the texture of the soil, correcting problems of compaction or excessive softness, and acting on chemical and/or biological reactions (Rodríguez-Vila et al., 2015; Castán et al., 2016).

The preparation of the compost and vermicompost that will be used in the different treatments as organic amendments; the characterization of the physicochemical properties of the initial soil, the compost, and the vermicompost by means of different of laboratory analytical techniques; and the determination of the initial conditions of the amendments and their feasibility in the remediation of a saline soil have been the objectives of this work.

\section{MATERIAL AND METHODS}

\section{Characteristics and location of the sampling site}

Soil samples were taken from the municipality of Munitepec de Madero in the municipality of Tlahuelilpan with coordinates $20^{\circ} 12.47^{\prime} 28^{\prime \prime} \mathrm{N}$ and $99^{\circ} 20.74^{\prime} 04^{\prime \prime} \mathrm{W}$. The municipality has a temperate semidry climate, with an average annual rainfall of $504 \mathrm{~mm}$ and average temperature that ranges between 14 and $18{ }^{\circ} \mathrm{C}$ (INEGI, 2014, 2017; SMN-CONA, 2016). The potential land use is mainly agricultural and livestock production. Agriculture is $43 \%$ mechanized and continuous. These soils require irrigation, which is conducted with wastewater from the Valley of Mexico and its suburbs. The flood irrigation system has been used for more than 80 years.

Random samples were taken at $20-\mathrm{cm}$ depth from a hectare of land, divided into quadrants, with 13 subsamples being collected for each quadrant ( 52 in total). The samples were then cleaned manually to remove stones and plant debris, then mixed and homogenized, and finally were sieved through $2.0 \mathrm{~mm}$ mesh.

\section{Preparation, collection and sampling of compost and vermicompost}

The compost was prepared in the Institute of Agricultural Sciences (ICAP) of the Universidad Autonoma del Estado de Hidalgo (UAEH). For the preparation of the compost, where the materials were to be deposited on the soil was excavated, so the heat of the soil would help accelerate the decomposition process. The compost was prepared by mixing organic waste and combining layers of dry matter, fresh matter, agricultural soil, and protective straw according to the 2010 SAGARPA compost manual.

Vermicompost was prepared using red Californian earthworms (Eisenia foetida), which were acquired from the worm farm of the Institute of Agricultural Sciences (ICAP). Preparation was carried out at a small scale, following the same guidelines as for compost and using the same materials, with special care taken with the container system to prevent earthworm escape.

The moisture in the compost and vermicompost was monitored during its maturation process and remained between 45 and $60 \%$, its optimum range, and once maturation was complete, and the compost and vermicompost had been stored and ready for use, the humidity might drop to between 10 and $20 \%$.

\section{Physical and chemical analyses performed}

The Zeta potential (ZP), electrophoretic mobility (ME), and isoelectric point (IP) or zero load point were determined for the initial soil sample and the previously prepared compost and the vermicompost by means of Zetasizer-Nano equipment from the company Malvern (Malvern, 2009); the electrical conductivity (EC) and pH were obtained from the soil saturation extract according to method AS-13 (DOF, 2002). The distribution of colloidal particle sizes of the soil was also determined by means of a laser size analyzer, model LS13-320 by Beckman Coulter. Likewise, X-ray diffraction (DRX) was determined using X-ray equipment (model INEL), and scanning electron microscopy with coupled energy-dispersive spectroscopy (MEB-EDS, JSM6300 equipment from JEOL) was also used. The apparent density and the bulk density (AS-03 and AS04, respectively) and the soil moisture content (AS05) were also determined; likewise, an elementary analysis of $\mathrm{C}, \mathrm{N}$, and $\mathrm{H}$ was performed using Perkin Elmer elemental analyzer equipment, model Series II CHNS/O 2400; and the textures of the soil (AS-09) and the organic matter component (AS-07) were determined by the Bouyoucus method.

\section{Statistical analysis}

Inferential statistical analysis was performed, and significant differences were determined using Tukey's test. 


\section{RESULTS AND DISCUSSION}

\section{Results for the initial soil, compost, and vermicompost}

ZP, electrophoretic mobility (ME), EC, pH, IP, and distribution of colloidal particle sizes of the initial soil, compost, and vermicompost

Table 1 shows the average values of the ZP, $\mathrm{EM}, \mathrm{EC}$, and $\mathrm{pH}$, obtained from the saturation extract according to AS-16 (DOF, 2002), in the original sample before application of the amendments; the values of the standard deviation and the percentage of the coefficient of variation are also indicated, expressed as \% RSD. Tables 2 and 3 show the average values of the ZP, EM, $\mathrm{EC}$, and $\mathrm{pH}$ obtained in the saturation extract, according to AS-16 (DOF, 2002) of the compost and the initial vermicompost, respectively.

When the characteristics of the saturation extract of the original sample soil were compared among the soil, compost, and vermicompost, more-stable colloids were observed in the compost and vermicompost, with more negative ZP values; this was also true for EM, which showed more negative values than the original soil value and lower EC values, as well as a decrease in the $\mathrm{pH}$. This finding corresponds with the findings reported by Wiszniewska et al. (2016) who suggested that an accumulation of or increase in organic matter in soil slightly lowers the soil $\mathrm{pH}$.

Therefore, the organic amendments of compost and vermicompost are expected to be beneficial for increasing the organic load of this soil and serving to reduce the soil sodium, as well as for reducing the salinity or conductivity, and would contribute to improved soil permeability, thereby increasing aeration and providing better soil structure.

Table 1: Results of the Zeta potential, electrophoretic mobility, conductivity, and $\mathrm{pH}$ in initial soil samples.

\begin{tabular}{cccrc}
\hline \multicolumn{5}{c}{ Initial soil $(\mathrm{n}=10)$} \\
\hline & ZP & Mob & \multicolumn{1}{c}{ EC } & pH \\
\hline mV & $\mu \mathrm{m} . \mathrm{s} / \mathrm{V} . \mathrm{cm}^{2}$ & $\mathrm{dS} / \mathrm{m}$ & - \\
Mean & -11.64 & -0.90 & 5.61 & 8.21 \\
Std Dev & 1.08 & 0.09 & 0.62 & 0.03 \\
RSD \% & 9.32 & 10.31 & 11.07 & 0.42 \\
Minimum & -9.69 & -1.07 & 4.49 & 8.16 \\
Maximum & -12.6 & -0.76 & 6.48 & 8.25 \\
\hline
\end{tabular}

Table 2: Results of Zeta potential, electrophoretic mobility, conductivity, and $\mathrm{pH}$ in initial compost samples.

\begin{tabular}{ccccc}
\hline \multicolumn{5}{c}{ Initial compost $(\mathrm{n}=10)$} \\
\hline & $\mathrm{ZP}$ & $\mathrm{Mob}$ & $\mathrm{EC}$ & $\mathrm{pH}$ \\
\hline $\mathrm{mV}$ & $\mu \mathrm{m} . \mathrm{s} / \mathrm{V} . \mathrm{cm}^{2}$ & $\mathrm{dS} / \mathrm{m}$ & - \\
\hline Mean & -28.40 & -2.2351 & 3.255 & 7.96 \\
Std Dev & 0.431 & 0.043 & 0.015 & 0.63 \\
RSD \% & 1.52 & 1.91 & 0.46 & 7.91 \\
Minimum & -27.6 & -2.166 & 3.24 & 6.8 \\
Maximum & -29.1 & -2.312 & 3.29 & 8.75 \\
\hline
\end{tabular}

Table 3: Results of Zeta potential, electrophoretic mobility, conductivity, and pH in initial vermicompost samples.

\begin{tabular}{|c|c|c|c|c|}
\hline \multicolumn{5}{|c|}{ Initial vermicompost $(n=10)$} \\
\hline Sample & $\mathrm{ZP}$ & Mob & EC & $\mathrm{pH}$ \\
\hline & $\mathrm{mV}$ & $\mu \mathrm{m} . \mathrm{s} / \mathrm{V} \mathrm{cm^{2 }}$ & $\mathrm{dS} / \mathrm{m}$ & - \\
\hline Mean & -26.04 & -2.042 & 2.17 & 7.72 \\
\hline Std Dev & 0.570 & 0.044 & 0.010 & 0.05 \\
\hline RSD \% & 2.19 & 2.16 & 0.47 & 0.6 \\
\hline Minimum & -27.6 & -2.166 & 3.24 & 7.39 \\
\hline Maximum & -29.1 & -2.312 & 3.29 & 8.02 \\
\hline
\end{tabular}

Homogeneity is observed in the distribution of the ZP (Figure 1), and the EM indicates a relatively low stability of the colloids in the initial soil suspension. The stability of the colloidal particles occurs in the range $>30 \mathrm{mV}$ and $<-30$ $\mathrm{mV}$ (Malvern, 2009). Therefore, the colloid suspension of the soil with a $\mathrm{ZP}$ of $-11.64 \mathrm{mV}$ lies in a region of instability. Similarly, the ZP of the compost and the vermicompost $(-28.40 \mathrm{mV}$ and $-26.04 \mathrm{mV}$, respectively) indicates a tendency for stability by the colloids that are present.

The EM is $-0.90 \mu \mathrm{m} . \mathrm{s} / \mathrm{V} . \mathrm{cm}^{2}$ in the initial soil and twice that for compost and vermicompost $(-2.24 \mu \mathrm{m} . \mathrm{s} / \mathrm{V}$. $\mathrm{cm}^{2}$ and $-2.04 \mu \mathrm{m} . \mathrm{s} / \mathrm{V} . \mathrm{cm}^{2}$, respectively). This result is explained by the salinity of the soil being associated with the solid phases of the soil and the soil solution; this causes an indirect effect on the state of the soil colloids (instability or stability) and a direct effect on the water availability (lower availability) (Busoms et al., 2015; Murli et al., 2016). Likewise, the ZP is directly associated with the EM because the measurement of the $\mathrm{ZP}$ is a measure of the EM. Likewise, the alkaline $\mathrm{pH}$ and the sodicity/alkalinity are associated with the quality of the interchangeable ions, which cause a direct effect on the 
state of the soil colloids (instability) and an indirect effect on the availability of nutrients. For this reason, in saline or saline-sodic soils, crop yields are reduced due to the low nutrient and water availability (Busoms et al., 2015).

The colloidal fractions of the initial soil are classified as a phase of instability and, according to the $\mathrm{pH}$, play important roles in the availability of nutrients for the plants. An acidic or alkaline $\mathrm{pH}$ can induce an element of deficiency.
The compost and the vermicompost apparently buffer the $\mathrm{pH}$ of the saline solution and the alkalinity of the unstable phase of the initial soil due to the salinity contributed by sodium (Ozenc; Caliskan, 2001; Vijayasatya et al., 2015).

An inversely proportional correlation between the $\mathrm{EC}$ and the ZP in the initial soil is clearly evident as shown in Figure 2. This can be explained considering that when a particle moves, the ions of the diffuse layer remain at the

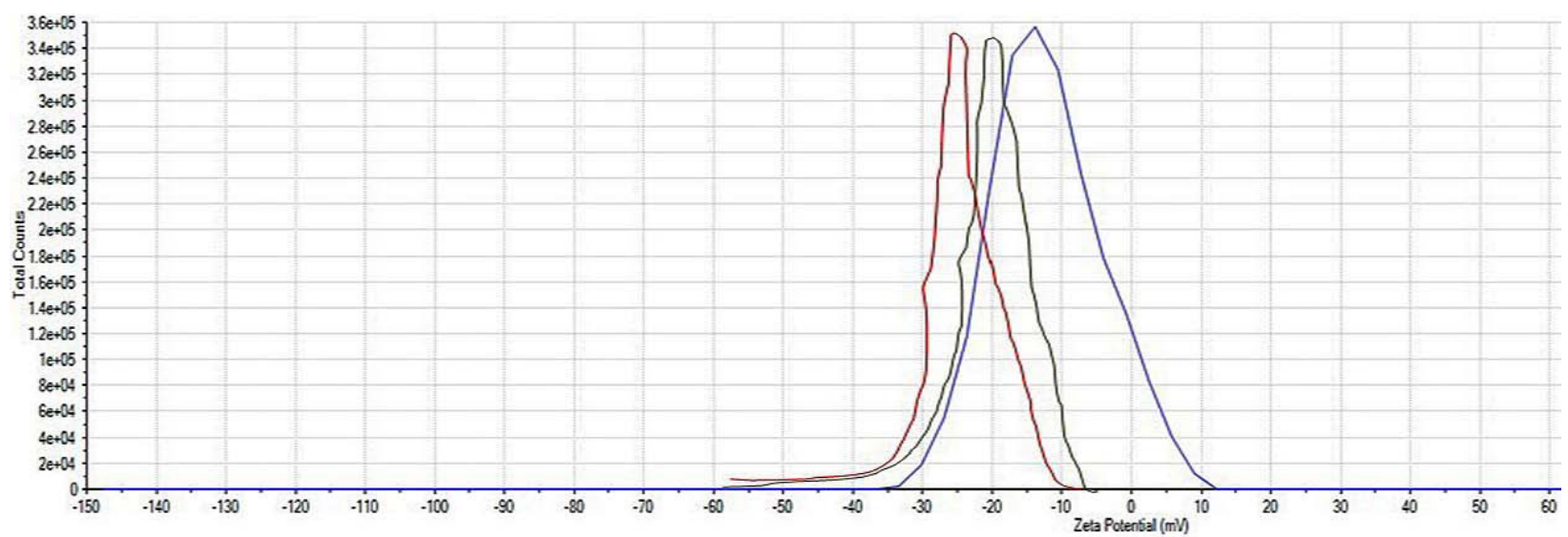

Figure 1: Distribution of the initial Zeta potential (homogeneous). The ZP (-11.64 mV) for the initial soil (blue line), the compost (red line) $(-28.40 \mathrm{mV})$, and the vermicompost (green line) $(-26.04 \mathrm{mV})$.

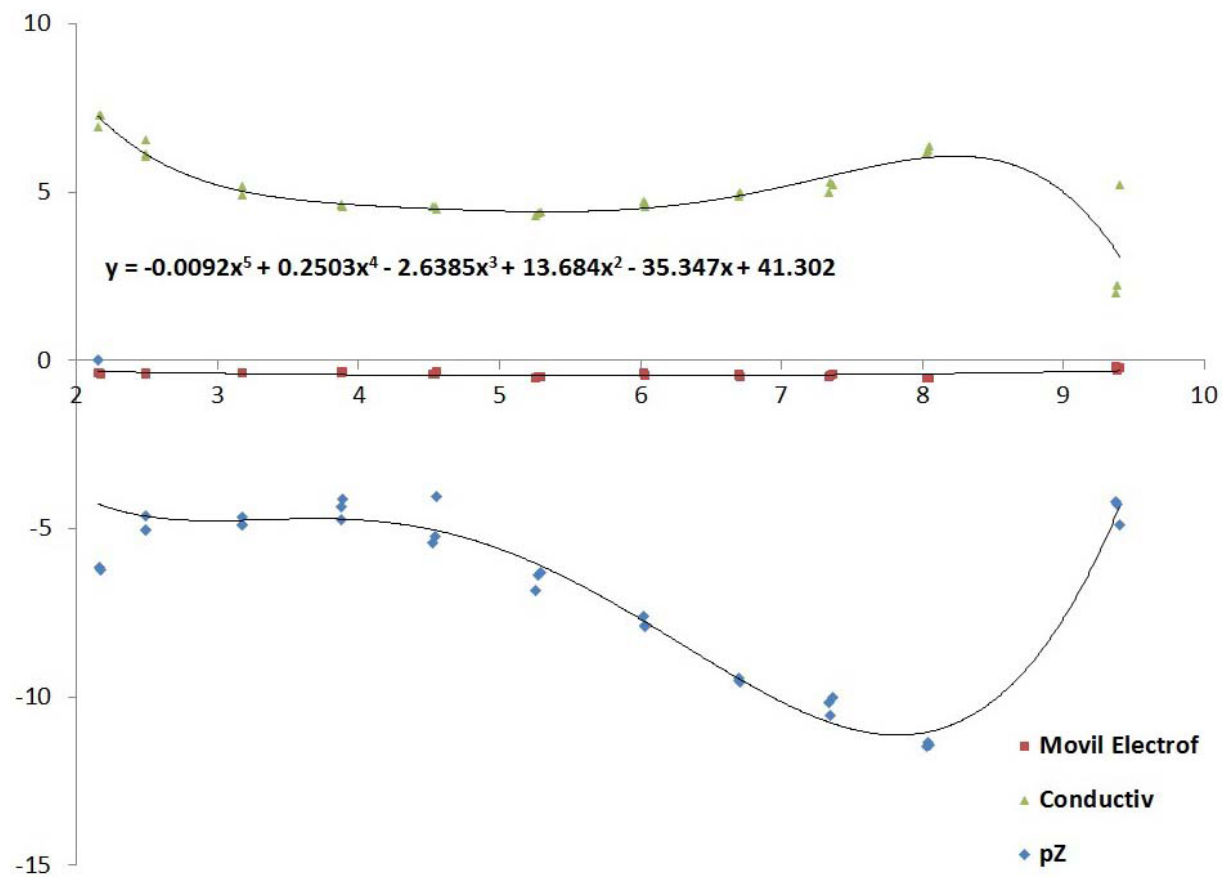

Figure 2: Correlation between conductivity, Zeta potential, and electrophoretic mobility in the initial soil. For reasons of scale, no change is observed in the line of the electrophoretic mobility. 
"end" of the tail (giving a comet effect), and the new ions "try to enter" in the diffuse layer "in front" of the particle. However, the restoration of the diffuse layer in front of the particle does not appear to be instantaneous, and as a consequence, the thickness of the diffuse layer decreases in front and further back (Salager, 1988). Therefore, the hypothesis of a diffuse concentric layer for the particle is not met when colloidal particles are in motion.

The result is a delayed effect (an increase in the distance between the front layer and the diffuse layer), which occurs because a decrease in ZP occurs when the displacement of the diffuse layer ions reduces the local intensity of the electric field. On the other hand, the surface charges of the particle may be more mobile, suggesting a change in the EC of the medium (greater mobility of ions). Then, the particle has a greater surface conductance that also results in an increase in the EC of the medium.

The delay effect becomes important for high values of ZP (positive or negative) and for particles between 0.1 $<\mathrm{x}<100 \mu \mathrm{m}$ (Salager, 1988). The delay effect then, is a concern because an evaluation of the distribution and size of the particles in the initial suspension of soil shows an average size of $59.26 \mu \mathrm{m}$, a median of $48.19 \mu \mathrm{m}$, and a mode of $72.94 \mu \mathrm{m}$. However, the ZP is not high.

As shown in Figure $3 \mathrm{a}$ and $\mathrm{b}$, the correlation and variation of EM with the variation in $\mathrm{pH}$ can be detected at a larger scale (Figure 3b). A direct correspondence can be observed between the EM and the ZP (3a). The instrument accurately measures the electrophoretic mobility of the charged particles, which is expressed as microns/second per volts/centimeter ${ }^{2}$. The first term, microns per second, simply represents velocity, whereas the second, volts per centimeter ${ }^{2}$, is an expression of the electric force of the field. The ZP is then calculated from the measurements of electrophoretic mobility (Malvern, 2009). The higher the relative value of the dielectric constant, the greater the EC of the medium must be, and the inverse relation of the electrophoretic mobility with the zeta potential can be verified (Prieto García et al., 2009; Castro et al., 2016).

The system measures the Doppler shift caused by a particle that moves electrophoretically. A pair of electrodes are inserted into the fluid sample, and the system applies an electric field that causes the particles to reach a velocity known as the electrophoretic velocity, as shown in Equation 1:

$$
\mathrm{U}=\mu \mathrm{E}
$$

where $\mathrm{U}$ is the electrophoretic velocity, $\mu$ is the electrophoretic mobility $\left(\mu \mathrm{m} / \mathrm{s} / \mathrm{V} / \mathrm{cm}^{2}\right)$, and $\mathrm{E}$ is the electric field.
The Doppler effect is the apparent change in frequency of a wave produced by the relative movement of the source, with respect to its observer (Figure 4).

In the case of the visible spectrum of electromagnetic radiation, if the object moves away, its light changes to longer wavelengths, producing a change toward the red part of the spectrum. If the object approaches, its light has a shorter wavelength, moving toward blue. This deviation toward red or blue is very slight even for high velocities (Rosen; Gothard, 2009).

The positive and negative electrodes change in polarity in such a way that the particles move continuously from one electrode to the other. The sample that is between the electrodes is illuminated with a laser beam and the dispersion of this laser beam is used to determine the Doppler shift caused by the movement of the particles. Equation 2 is used to determine electrophoretic mobility with the measured Doppler shift and the optical and geometric properties of the known measurement device as follows:

$\mu=\left(\lambda_{\mathrm{o}} / \mathrm{n} \sin \theta\right)(1 / \mathrm{E}) \Delta v$

where $\lambda_{0}$ is the wavelength of the laser beam, $n$ is the refractive index, $\theta$ is the angle at which scattered light is detected, $\mathrm{E}$ is the electric field, and $\Delta v$ is the deviation of the Doppler frequency. With the known electrophoretic mobility, the Smoluchowski approximation is used to obtain the ZP $(\zeta)$, as indicated by Equation 3 (Tibaquirá et al., 2007):

$\zeta=\frac{\eta \mu}{\varepsilon}$

where $\eta$ is the viscosity of the fluid, and $\varepsilon$ is the dielectric constant.

Therefore, the greater the relative value of the dielectric constant, the greater the value must be for the $\mathrm{EC}$ of the medium, and its inverse relation with the ZP can be verified (Prieto García et al., 2009, Castro et al., 2016).

When a particle suspension is subjected to a gravitational field, the diffuse layer of the particles is partially torn off, and a difference in electric potential occurs along the particle in the direction of the drop. The sum of these elementary effects results in an electrokinetic phenomenon called sedimentation potential or the Dorn effect (Wall, 2010). The problem is extremely complex because it is microscopic (at the scale of the particle) and macroscopic (at the scale of the system). 


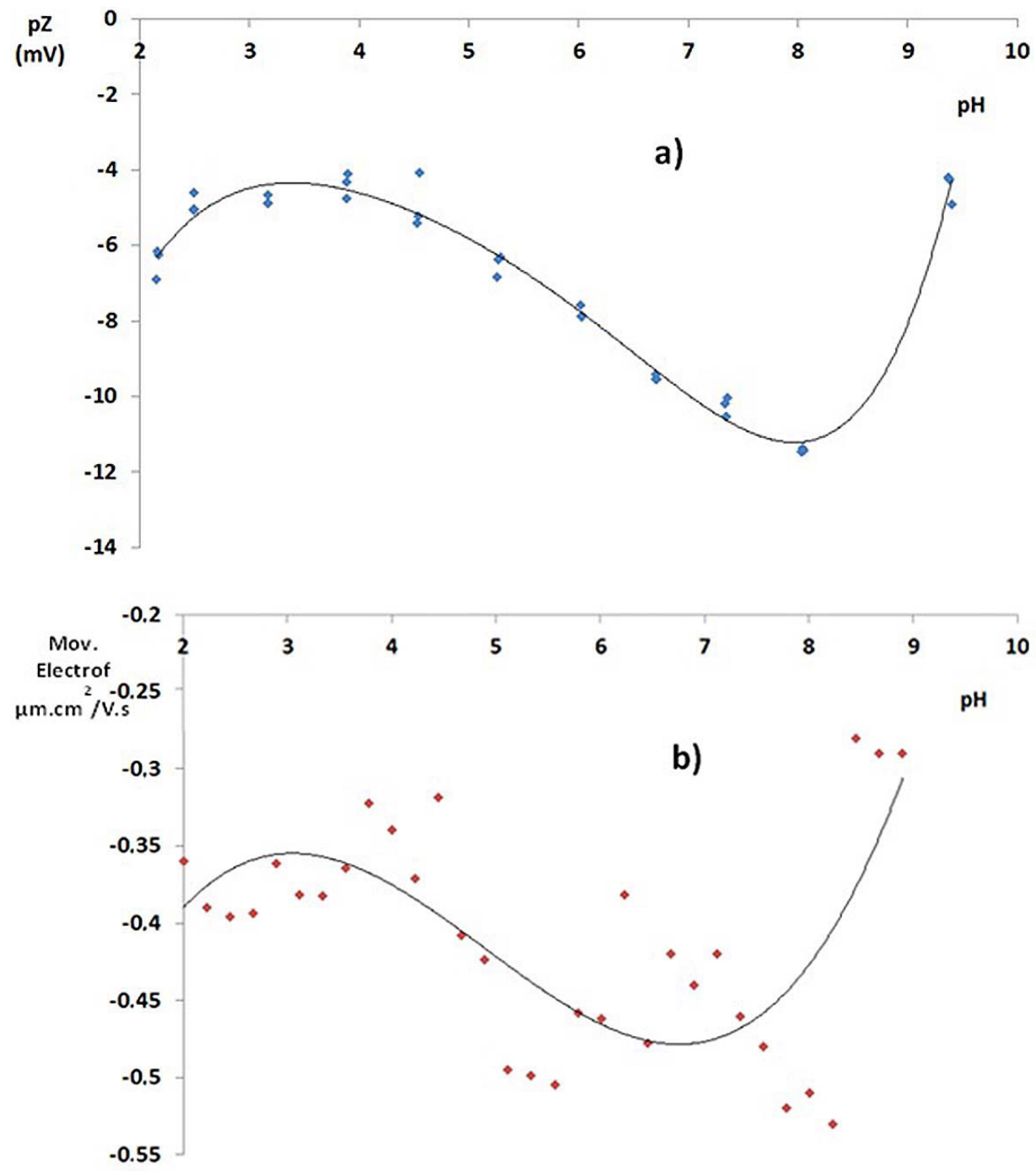

Figure 3: (a) Correlation of ZP vs electrophoretic mobility; (b) Correlation of $\mathrm{pH}$ vs electrophoretic mobility in the soil saturation extract.

On the one hand, the particles of a system are not all the same size, and therefore have neither the same drop velocity nor the same flow potential. In addition, many different types of particles may be present. Finally, in a closed system, the total volumetric flow is zero, and a withdrawal of the solvent occurs to compensate for the sedimentation. In addition, Brownian diffusional phenomena may be present in the particles.

On the other hand, the ZP is calculated directly from the measurement of the electrophoretic velocity. In general, the variation in $\mathrm{ZP}$ is studied according to the concentration of electrolytes in the solution. When the concentration of electrolytes is high, a compression of the diffuse layer occurs, since the Debye length $(\mathrm{k})$ varies inversely with the electrolyte concentration; this implies a decrease in ZP. In an electrolyte or a colloid, the Debye length is usually denoted by $\mathrm{k}^{-1}$ and is determined using Equation 4 :

$\kappa^{-1}=\sqrt{\frac{\varepsilon_{r} \varepsilon_{0} R T}{2 F^{2} C_{0}}}$

where $\mathrm{e}_{0}$ is the electric permittivity of the free space, $\mathrm{e}_{\mathrm{r}}$ is the dielectric constant, $\mathrm{R}$ is the universal gas constant, $\mathrm{T}$ is the absolute temperature in ${ }^{\circ} \mathrm{K}, \mathrm{F}$ is the Faraday constant, and $\mathrm{C}_{0}$ is the molar concentration of the electrolyte. 


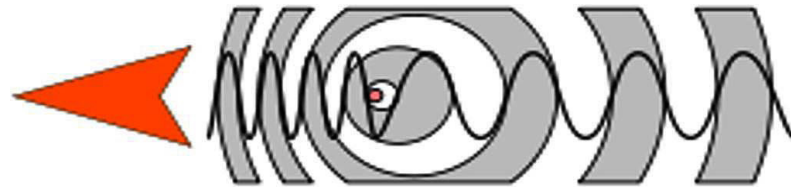

Figure 4: Diagram of the Doppler effect.

However, the EC of the medium evidently increases due to the increase of $\mathrm{C}_{0}$ (Stern et al., 2007; Prieto García et al., 2009).

From an agronomic point of view, salinity is expressed in terms of EC, which indicates the velocity with which the electric current passes through a saline solution, which is proportional to the concentration of salts in the solution. EC is measured in millimhos per cubic centimeter $\left(\mathrm{mmhos} / \mathrm{cm}^{3}\right)$ also known as decisiemens per meter $\left(\mathrm{dSm}^{-1}\right)$ (Mata et al., 2014).

\section{X-ray diffraction (XRD) and Scanning Electron Microscopy (SEM) with coupled EDS}

XRD of the initial soil sample is shown in Figure 5, and Table 4 shows the identification of the phases present. In descending order, the phases of albite, kaolinite, and halloysite appear as the majority. As reported by Yu et al. (2015), in saline soils, amounts of $9.00 \pm 0.55 \%$ of albite and $5.34 \pm$ $0.16 \%$ of kaolinite are detected as clays, and in addition, 9.20 $\pm 0.25 \%$ of quartz and $22.1 \pm 1.26 \%$ of feldspar were detected in the area, indicating they are primary minerals. Saline soils have also been reported to be rich in phases of albite, dolomite $\left[\mathrm{CaMg}\left(\mathrm{CO}_{3}\right)_{2}\right]$, calcite, anorthite, muscovite, and quartz (Druzbicka; Rufaut; Craw, 2015; Prakash et al., 2016).

SEM with EDS, also allows detecting the presence of elements such as $\mathrm{Si}, \mathrm{Al}, \mathrm{Ca}, \mathrm{Mg}, \mathrm{Na}, \mathrm{K}, \mathrm{Fe}, \mathrm{S}$, and $\mathrm{P}$, among others (Figure 6 and Table 5), which corresponds to the minerals identified by the DRX.

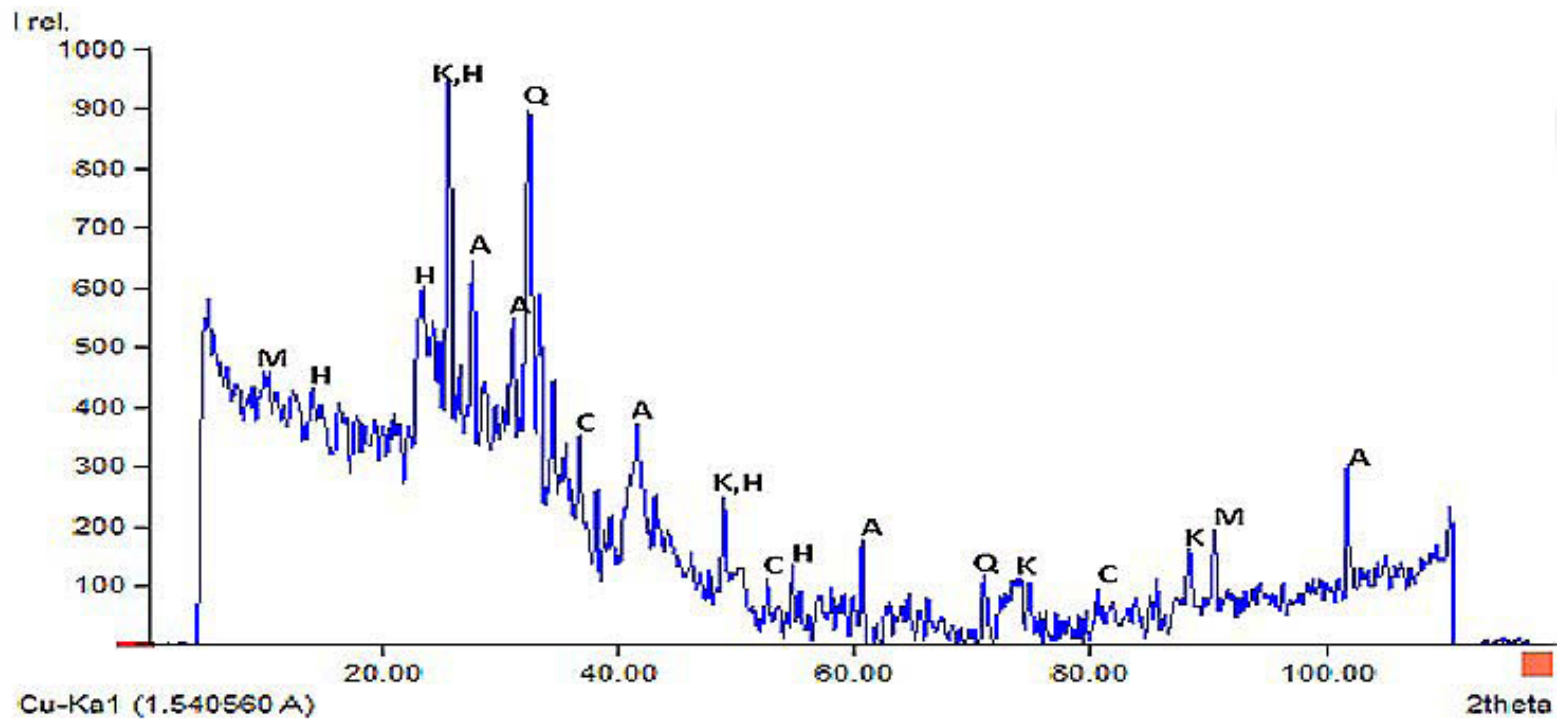

Figure 5: DRX of the initial saline soil.

Table 4: Minerals identified by XRD in the initial soil (Benavente et al., 2011).

\begin{tabular}{cccc}
\hline Symbol & Name & Formula & Reference \\
\hline $\mathrm{A}$ & Albite & $\mathrm{Na}_{0.95} \mathrm{Ca}_{0.05} \mathrm{Aln}_{1.05} \mathrm{Si}_{2.95} \mathrm{O}_{8}$ & Cornelis; Cornelius (2006) \\
$\mathrm{K}$ & Kaolinite & $\mathrm{Al}_{2} \mathrm{Si}_{2} \mathrm{O}_{5}(\mathrm{OH})_{4}$ & Torres et al. (2011) \\
$\mathrm{H}$ & Halloysite & $\mathrm{Si}_{4} \mathrm{Al}_{4} \mathrm{O}_{10}(\mathrm{OH})_{8} \cdot 4 \mathrm{H}_{2} \mathrm{O}$ & Soil Science Society of America (2008); \\
$\mathrm{M}$ & Montmorillonite & $(\mathrm{Na}, \mathrm{Ca})_{0,6}(\mathrm{Al}, \mathrm{Mg})_{2} \mathrm{Si}_{4} \mathrm{O}_{10}(\mathrm{OH})_{2} \cdot \mathrm{nH}_{2} \mathrm{O}$ & Carrillo et al. (2014) \\
Q & Quartz & $\mathrm{SiO}_{2}$ & Pargas-Rodríguez et al. (2008) \\
$\mathrm{C}$ & Calcite & $\mathrm{CaCO}_{3}$ & Pimentel et al. (2012) \\
\hline
\end{tabular}




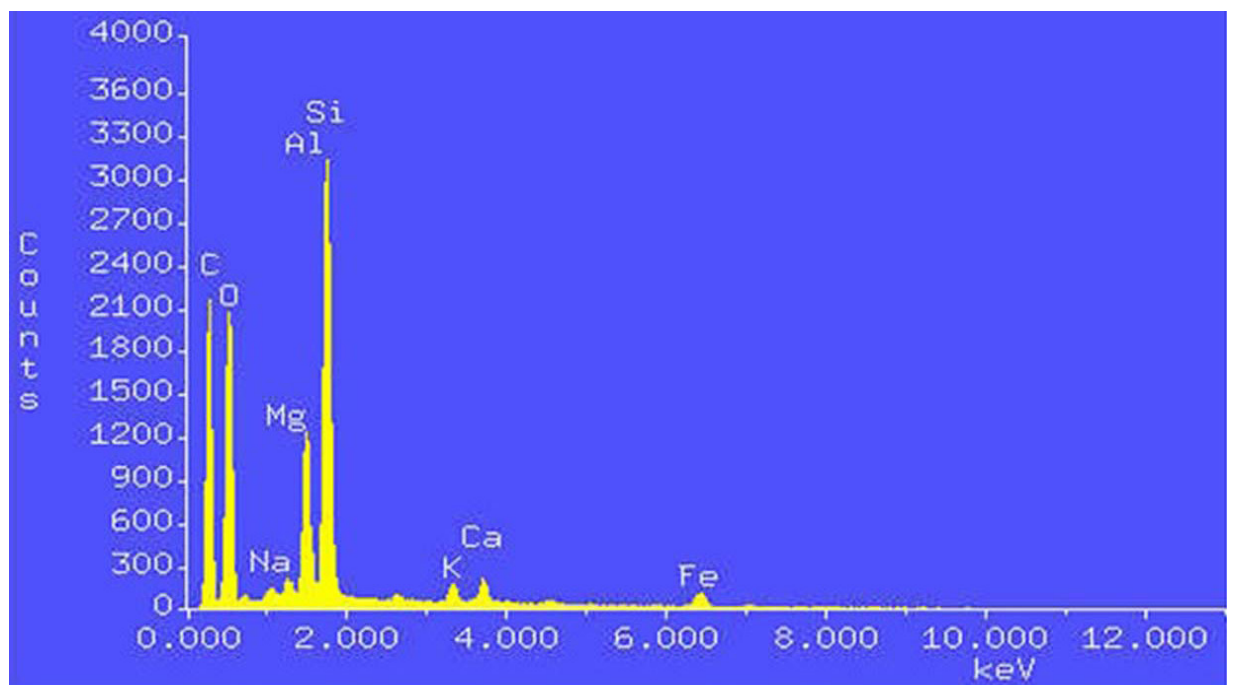

Figure 6: EDS spectrum of the initial Tlahuelilpan soil (Correction Acc. Volt. $=15 \mathrm{kV}$ Take-off Angle $=42.73 \mathrm{deg})^{[29]}$ (Scaglia; Muzio, 2014).

From the semiquantitative results of the EMB-EDS, the soil is identified as a magnesium-sodic soil, and the elements shown in Table 5 would need to be quantified by atomic absorption spectroscopy (AAS). The soil is poor in nitrogen and contains phosphorus possibly in the form of phosphate.

As a sodic-magnesium soil, the soil is classified as Solonetz (FAO, 2007). Solonetz soils have a somewhat clayey, dense, highly structured subsurface horizons, with a high proportion of adsorbed $\mathrm{Na}$ and/or Mg ions. Solonetz soils often have different common international names such as alkaline soils and sodic soils.

Table 5: Semiquantitative composition of the initial soil.

\begin{tabular}{clr}
\hline Element & k-ratio & Wt \% \\
\hline Na-k & 0.0339 & 8.98 \\
K-k & 0.0124 & 3.29 \\
Mg-k & 0.0645 & 17.10 \\
Ca-k & 0.0164 & 4.35 \\
Al-k & 0.044 & 11.66 \\
Si-k & 0.1384 & 36.68 \\
S-k & 0.0009 & 0.24 \\
C-k & 0.0283 & 7.50 \\
P-k & 0.0008 & 0.21 \\
N-k & 0.000 & 0.00 \\
Fe-k & 0.0377 & 9.99 \\
Total & 0.3773 & 100.00 \\
\hline
\end{tabular}

As a sodic-magnesium soil, the initial soil is classified as Solonetz (FAO, 2007). Solonetz soils have a subsurface horizon that is somewhat clayey, dense, and strongly structured, with a high proportion of adsorbed $\mathrm{Na}$ and/or Mg ions. Solonetz soils often have different common international names such as alkaline soils and sodic soils.

\section{Results of other physical and chemical analyses}

The results of apparent density (DA) and bulk density (DB) are shown in Table 6. The variations in the DB of the analyzed materials are determined by the organic matter content $(\mathrm{OM})$, where the highest $\mathrm{OM}$ values correspond to the lower values of DB. This is concordant with that reported by Ruehlmann and Körschens and by Medina and collaborators (Table 6) (Ruehlmann and Körschens, 2009; Medina Guerrero et al., 2015). The DB of the minerals identified by XRD and present in the soil sample is, on average, $2.60 \mathrm{~g} / \mathrm{cm}^{3}$. The DA of the soil was approximately $50 \%$ lower than the DB. The DB and DA of the vermicompost correspond to those reported by Medina and collaborators (Medina Guerrero et al., 2015).

According to the humidity results, a relatively low humidity can be observed in the soil under study, whereas the humidity of the compost and the vermicompost were 3.1 and 3.8 times higher.

The texture indicates the relative content of the different sized particles, such as the sand, silt, and clay, in the soil. According to the results, the textural class of the soil in the study is considered a sandy-clayey-loam (USDA, 2003; Carrillo et al., 2014). 
Table 6: Results of other physical and chemical analyses of the initial soil and compost and vermicompost samples. The standard deviation is in parentheses.

\begin{tabular}{ccccc}
\hline & Bulk Density (DB) & Apparent Density (DA) & Humidity & OM \\
\hline Samples & $\mathrm{g} / \mathrm{cm}^{3}$ & $\mathrm{~g} / \mathrm{cm}^{3}$ & $(\%)$ & $(\%)$ \\
\hline Soil & $2.47(0.11)^{\mathrm{c}}$ & $1.14(0.07)^{\mathrm{c}}$ & $5.34(0.41)^{\mathrm{a}}$ & $3.34(0.23)^{\mathrm{a}}$ \\
Compost & $1.74(0.09)^{\mathrm{b}}$ & $0.52(0.03)^{\mathrm{b}}$ & $16.45(0.68)^{\mathrm{b}}$ & $20.25(0.72)^{\mathrm{b}}$ \\
Vermicompost & $1.36(0.08)^{\mathrm{a}}$ & $0.48(0.03)^{\mathrm{a}}$ & $20.36(0.69)^{\mathrm{c}}$ & $32.43(1.05)^{\mathrm{c}}$ \\
\hline
\end{tabular}

Organic matter is the most commonly used indicator to assess soil quality (Maicelo, 2012). The organic matter, determined in accordance with the Mexican Official Standard (DOF, 2002), shows the nutrient poverty in the study soil $(3.34 \%$, which is low to medium level for nonvolcanic soils and very low for volcanic soils). For obvious reasons, the compost and vermicompost have much higher values (Table 6). The organic matter values obtained from the compost and vermicompost are similar to reported values (Bharti et al., 2018).

Some of the carbon present in the soil is in the form of $\mathrm{HCO}_{3}{ }_{3}^{-}$and some as $\mathrm{CO}_{3}^{2-}$. The bicarbonate content was $96.11 \pm 0.23 \mathrm{mg} / \mathrm{L}$ (i.e., $1.58 \mathrm{meq} / \mathrm{L}$ ) and carbonate $1.20 \pm$ $0.11 \mathrm{mg} / \mathrm{L}(0.02 \mathrm{meq} / \mathrm{L})$. The carbon corresponds to the $\mathrm{pH}$ found in the saturation extract (8.21), thus corroborating, in part, that the conductivity and salinity of this soil obtained from the saturation extract may be due to the presence of carbonate and bicarbonate anions, among other causes.

The total alkalinity expressed as $\mathrm{CaCO}_{3}$ yielded $177.4 \pm 2.36 \mathrm{~g}$ of $\mathrm{CaCO}_{3} / \mathrm{kg}$ of soil. According to Lin and collaborators ${ }^{[3]}$ (Lin et al., 2016), soluble salt compounds such as carbonates and bicarbonates accumulate in the soils, resulting in soil salinization and alkalization.

\section{CONCLUSIONS}

The application of organic amendments favor the recovery of saline-sodic soils. By using compost and vermicompost as organic amendments, a greater stability is achieved of the colloidal suspensions than in the initial soils as reflected by the more negative values of the $\mathrm{ZP}$. In the same way, the EC decreases, and corroboration was possible of an inverse correlation with respect to the variation in the $\mathrm{pH}$ between the $\mathrm{EC}$ and the $\mathrm{ZP}$ and a direct correlation between the EM and the ZP. This finding is explained as a delay effect, depending on the sizes of colloidal particles present in the soil saturation extracts and the organic amendments that were used, where much smaller colloidal particles were found in the amendments. The XRD showed the presence of the albite, kaolinite, and halloysite phases, with a high content of aluminosilicate and sodium. This was also corroborated by SEM-EDS. Regarding the low total carbon content in the soil, one part is in the form of bicarbonate, which corresponds to the moderately alkaline soil $\mathrm{pH}$ of 8.2. Continued studies are needed to evaluate the effectiveness of using organic amendments, such as compost and vermicompost, as well as to compare them with chemical amendments such as phosphogypsum with or without a combination of both amendments, for the bioremediation of saline soil. Improvements in sodium are expected in the organic loads of the soil, as well as a reduction in $\mathrm{pH}$, a possible leaching of excess sodium, and a partial regeneration of the original structure of the soil. The results of this study will serve as an application system that can be recommended to farmers.

\section{REFERENCES}

ACOSTA, L. Y. Estado del arte del tratamiento de aguas por coagulación-floculación. Revista ICIDCA. Sobre Ios Derivados de la Caña de Azúcar, XL(2):10-17, 2006.

BAGHEL, B.; SAHU, R.; PANDEY, D. Vermicomposting an economical enterprise for nutrient and waste management for rural agriculture. International Journal of Current Microbiology and Applied Sciences, 7(2):3754-3758, 2018.

BENAVENTE, D. Mineral identification by X-ray diffraction using online and free access databases. Enseñanza de las Ciencias de la Tierra, 20(3):280-289, 2011.

BUSOMS, S. et al. Salinity is an agent of divergent selection driving local adaptation of Arabidopsis thaliana to coastal habitats. Plant Physiol, 168:915-929, 2015.

CARRILLO, A. M. et al. Structural and textural characterization of a colombian halloysite. Revista Mexicana de Ingeniería Química, 13(2):563-571, 2014.

CASTÁN, E. et al. Managing the value of composts as organic amendments and fertilizers in sandy soils. Agriculture, Ecosystems and Environment, 224(2016):29-38, 2016. 
CASTRO, M. F. et al. Conductividad eléctrica, potencial de hidrógeno y humedad del sustrato en chile manzano (Capsicum pubescens re y p), con solución nutritiva al 50\%. Revista Congreso Nacional de Ingeniería y Tecnologías para el Desarrollo Sustentable, 2:17-22, 2016.

COMESW, R. V.; GONZÁLEZ, M. G. Y.; CONTI, M. E. Cambios en las propiedades de suelo de huerta y rendimiento de Beta vulgaris var. Cicla (I) por el uso de enmiendas orgánicas. Ciencia Del Suelo, 27(2):271-275, 2009.

CORNELIS, K.; CORNELIUS, H. Manual de mineralogía, basado en la Obra de J. Dana. Cuarta Edición. Editorial Reverté, Barcelona, España, p.110-114. 2006.

DOF. Diario Oficial de la Federación. NOM-021-RECNAT-2000. Norma Oficial Mexicana. Que establece las especificaciones de fertilidad, salinidad y clasificación de suelos. Estudios, muestreo y análisis. 2002.

DRUZBICKA, J.; RUFAUT, C.; CRAW, D. Evaporative mine water controls on natural revegetation of placer gold mines, Southern New Zealand. Mine Water and the Environment, 34(4):375-387, 2015.

FAO IUSS Grupo de Trabajo WRB. 2007. Base Referencial Mundial del Recurso Suelo. Segunda Edición. Primera actualización 2007. Informes sobre Recursos Mundiales de Suelos No. 103. FAO, Roma. 2007.

INEGI. Instituto Nacional de Estadística y Geografía. Anuario Estadístico y Geográfico de Hidalgo, p.35-45, 2014.

INEGI. Instituto Nacional de Estadística y Geografía. Anuario Estadístico y Geográfico de Hidalgo, p.26-40, 2017.

LIN, C. U. et al. Effect of different water application intensity and irrigation amount treatments of microirrigation on soil-leaching coastal saline soils of North China. Journal of Integrative Agriculture, 15(9):2123-2131, 2016.

MAICELO, Q.J. L. Indicadores de sustentabilidad en función del suelo y retención de carbono en la biomasa de Ceroxylon peruvianum Galeano, Sanín \& Mejía, en la cuenca media del río Utcubamba, Amazonas, Perú. Ecología Aplicada, 11(1):33-38, 2012.

MALVERN INSTRUMENT, INC. Setasizer Nano Essentials. Ed. Malver Inst. Catálogo Zeta-Sizer. Mano 382, Issue 5.0. Worcestershire, WR14, United Kingdom, 2009.

MATA-FERNÁNDEZ, I. et al. Dinámica de la salinidad en los suelos. Revista Digital del Departamento El Hombre y su Ambiente, 1(5):26-35, 2014.
MEDINA GUERRERO, M. L.; ZANOR, G. A.; SUÁREZ MENDOZA, J. A. Evaluación de un bioabono orgánico enriquecido para el mejoramiento de suelos arcillosos del Estado de Guanajuato. Jóvenes en la Ciencia, 1(2):89-93, 2015.

MEENA, M. D. Changes in biological and chemical properties of saline soil amended with municipal solid waste compost and chemical fertilizers in a mustard-pearl millet cropping system. Catena, 140, 1-8, 2016.

OUNI, Y. et al. Effects of two composts and two grasses on microbial biomass and biological activity in a salt-affected soil. Ecological Engineering, 60:363-369, 2013.

ÖZENC, N.; CALISKAN, N. Effect of husk, compost on hazelnut yield and quality. Acta Horticulturae, 556:559-566, 2001.

PÉREZ-SIRVENT, C.; MARTÍNEZ-SÁNCHEZ, M. J.; MARTÍNEZ, S. Composición mineralógica de los suelos: Indicador para la delimitación de las zonas de influencia Minera. Macla. Revista de la Sociedad Española de Mineralogía, (17):8790, 2013.

PIMENTEL, C.; PINA, C. M.; GNECCO, E. Crecimiento epitaxial de calcita sobre las Caras (104) de dolomita y kutnahorita. Macla. Revista de la Sociedad Española de Mineralogía, (16):166-168, 2012.

PRAKASH, P. J. et al. Study of Arabian Red Sea coastal soils as potential mineral dust sources. Atmospheric Chemistry and Physics, 16:11991-12004, 2016.

PRIETO GARCÍA, F. et al. Correlación de potencial zeta y parámetros fisicoquímicos en extractos de saturación de suelos del Distrito de riego-03, Valle del Mezquital, Hidalgo, México. Tropical and Subtropical Agroecosystems, 10(2):161-167, 2009.

RODRÍGUEZ-VILA, A. et al. Remediation of a copper mine soil with organic amendments: Compost and biochar versus Technosol and biochar. Spanish Journal of Soil Science, 5(2):130-143, 2015.

ROSEN, J.; GOTHARD, L. Q. Encyclopedia of Physical Science. Ed. Infobase Publishing. 155p. 2009.

RUEHLMANN, J.; KÖRSCHENS, M. Calculating the effect of soil organic matter concentration on soil bulk density. Soil Science Society of America Journal. (73)3:876-895, 2009.

SAGARPA Secretaría de Agricultura, Ganadería, Desarrollo Rural, Pesca y Alimentación. Boletín 5. Elaboración de composta. Subsecretaría de Desarrollo Rural. Dirección general de apoyos. 8p. 2010. 
SALAGER, J. L. Fenómenos electrocinéticos. Cuaderno FIRP S611-A. Laboratorio de formulación, interfases, reología y procesos. Universidad de Los Andes, versión 1, p.2-26. 1988.

SCAGLIA, F.; MUZIO, R. SEM - EDS mineralogical study of the cuaró sill Tacuarembó Dept. (Uruguay). Revista SUG. Sociedad Uruguaya de Geología, (19):36-46, 2014.

SMN-CONAGUA. Servicio Meteorológico Nacional. Comisión Nacional del Agua. Available in: <http:www.smn.cna.gob. mx/index.php>. Access in: March 20, 2016.

SOIL SCIENCE SOCIETY OF AMERICA. Glossary of Soil Science Terms. 80p. 2008.

STERN, E. et al. Importance of the Debye Screening Length on nanowire field effect transistor sensors. Nano Letters, 7(11):3405-3409, 2007.

TIBAQUIRÁ, J. E. et al. Zeta potential measurements of glass microspheres in phosphate buffers and ethylene glycol. Scientia et Technica, (XIII)35: 219-224. 2007.

TORRES, J. et al. Análisis comparativo de caolines de diferentes fuentes para la producción de metacaolín. Revista Latinoamericana de Metalurgia y Materiales, 31(1):3543, 2011.
UNITED STATES DEPARTMENT OF AGRICULTURE - USDA. Soil Survey Staff. Keys to soil taxonomy. 9th edition. Washington, DC, Natural Resources Conservation Service, USDA. 332p. 2003.

VARGAS-RODRÍGUEZ, Y. M. et al. Caracterización espectroscópica, química y morfológica y propiedades superfi ciales de una montmorillonita mexicana. Revista Mexicana de Ciencias Geológicas, 25(1):135-144, 2008.

VIJAYASATYA, N. et al. Leaching and reclamation of a biochar and compost amended saline-sodic soil with moderate SAR reclaimed water. Agricultural Water Management, 158:255-265, 2015.

WALL, S. The history of electrokinetic phenomena. Current Opinion in Colloid \& Interface Science, 15(3):119-124, 2010.

WISZNIEWSKA, A. et al. Natural organic amendments for improved phytoremediation of polluted soils: A review of recent progress. Pedosphere, 26(1):1-12, 2016.

YU, H. L. et al. Impact of addition of FGDB as a soil amendment on physical and chemical properties of an alkali soil and crop yield of maize in Northern China Coastal Plain. Journal of Chemistry, 2015:3-13, 2015. 